\title{
EMISSION OF MERCURY FROM POLISH LARGE-SCALE UTILITY BOILERS
}

\author{
Rafał Kobyłecki', Michał Wichliński', Grzegorz Wielgosz', Zbigniew Bis \\ 1 Department of Energy Engineering, Częstochowa University of Technology, Brzeźnicka 60a, 42-201 \\ Częstochowa, Poland, e-mail: rafalk@is.pcz.czest.pl
}

Received: 2016.08.16

Accepted: 2016.09.26

Published: 2016.11.01

\begin{abstract}
The article presents the results of investigations focused on the determination of mercury content in gas and solid samples. The emission of $\mathrm{Hg}$ was the result of coal combustion. The investigations were carried out in the selected power generation facilities operated with pulverized coal and circulating fluidized bed boilers. Analysis was carried out for the flue gases, as well as fuel and sorbent samples and the by-products of the combustion process (fly ash, slag, bottom ash, and the products of wet desulfurization technology). The determination of mercury content in solid samples was carried out using Lumex RA-915+ spectrometer with RP-91C attachment. The measurements of the mercury concentration in the flue gases were performed according to the cold vapor technique. The analysis of the results indicated that the main source of mercury is coal, but significant concentration was also determined for the biomass co-combusted in one of the facilities. Considerable amounts were also determined in fly ash and wet FGD (flue gas desulfurization) samples.
\end{abstract}

Keywords: mercury, coal combustion, power generation

\section{INTRODUCTION}

Apart from getting rid of 'commonly known' pollutants, such as sulfur dioxide, nitrogen oxides or particulate matter, large efforts are planned to be carried out in the near future to decrease the emission of mercury, and later on, of some other elements, such as selenium, cadmium or lead [1]. The most harmful element out of the above-mentioned ones seems to be, so far, mercury since numerous investigation results have indicated that even its low concentration may result in numerous diseases or death of human and other creatures [e.g. 2-4].

The total atmospheric emission of mercury is difficult to calculate but rough estimations are somewhere between 5,000 and 9,000 tons per year and roughly $40 \%$ of that amount is reported as the anthropogenic emission i.e. due to humanactivity $[5,6]$. In order to decrease the emission of $\mathrm{Hg}$ numerous efforts are undertaken as discussed e.g. the UN documents focused on minimization of the emission of mercury $[2,3]$.
Being a significant component of the anthropogenic emission, more than half of the mercury is 'sent' to the atmosphere as a result of the combustion of solid fuels at power plants or/and in individual households [7-9]. The problem associated with the emission of mercury seems to be particularly serious for Poland where almost $85 \%$ of the energy is converted due to the combustion of coal (hardcoal and lignite). Rough estimations $[5,6]$ also confirm that the power generation sector is responsible for over $50 \%$ of the total atmospheric mercury emission. Since in recent years Polish power generation facilities consumed roughly over $40 \mathrm{Mt}$ of the hard coal and over $60 \mathrm{Mt}$ of lignite [7] the antropogenic emission of $\mathrm{Hg}$ could be estimated at somewhere between 10 and $20 \mathrm{Mt}$ per year.

According to previous research carried out by various authors [e.g. 8-11] the Polish hard coals contain roughly $100 \mathrm{ng} / \mathrm{g}$ of mercury that is an average value compared to the data for other coals in the world. It has to be emphasized, however, that the mercury content in lignite (brown coal) is much higher and often exceeds $200 \mathrm{ng} / \mathrm{g}$ [8-11]. 
Since so far the concentration of mercury was mainly reported for Polish coal samples [9-11] there is still a lack of data for other possible $\mathrm{Hg}$ containing substances, such as e.g. the combustion by-products (ashes and flue gas). Determination of the mercury content in those samples is crucial [12] from the environmental point of view in order to avoid an uncontrolled emission of mercury and work-out on an efficient and environmentally-friendly technology for mercury capture before those by-products could be re-used or safely dumped. The data in this respect are presented in the current paper.

\section{INDUSTRIAL FACILITY AND MEASUREMENT METHODOLOGY}

The measurements of mercury emissions were conducted at two chosen power boilers. One of the combustors was a conventional 200 MW PC (pulverized coal) fired boiler with low$\mathrm{NO}_{x}$ burners, ESP (electrostatic precipitator) and wet flue gas desulfurization (FGD) plant, while the other combustor was also a roughly $200 \mathrm{MW}$ circulating fluidized bed (CFB) boiler with infurnace dry desulfurization system and the ESP for the removal of particulates. The PC boiler war fired with hard coal, while the CFB combustor was fed with a mixture of hard coal and biomass (90 $\mathrm{wt} \%$ of coal and $10 \mathrm{wt} \%$ of biomass).

For the current investigations, the analysis of mercury content in all samples was performed with the use of LUMEX RA-915+ spectrometer. The whole system is shown in Figure 1. The mercury concentration in gas phase (e.g. in the flue gas) could be determined directly by sucking the

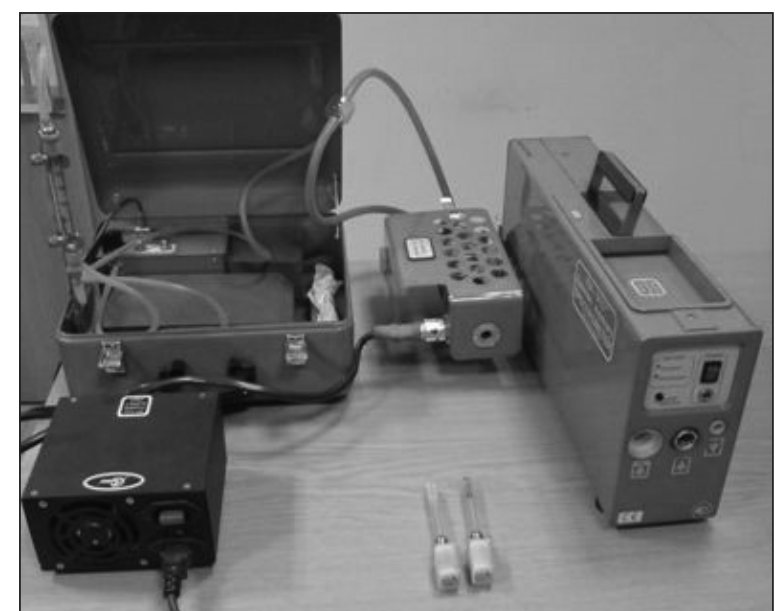

Fig. 1. Measurement setup for the investigation of mercury content in gas and solid samples.

flue gas by means of the internal pump and letting it to pass over the measurement section of the spectrometer. In order to determine the mercury concentration in solid samples the measurement device was coupled to an add-on device RP-91C presented in the middle section of Figure 1. The role of the add-on device was to provide the conditions for thermal destruction of the sample and reduction of the sample mercury to $\mathrm{Hg}^{0}$, as well as its evaporation to the gaseous phase. Since the sample was decomposed at over $800^{\circ} \mathrm{C}$ the mercury compounds were completely evaporated and the mercury content in the gas could be then analyzed online by the spectrometer RP-915+. The measurements could be conducted for mercury concentration between $0.5 \mathrm{mg} / \mathrm{kg}$ and $10000 \mathrm{mg} /$ $\mathrm{kg}$ with a maximum error of $\pm 20 \%$ [28]. The determination of the mercury content in the samples was based on Zeeman differential atomic absorption spectrometry with the use of high frequen-

Table 1. Some chosen main parameters of the fuels combusted in the boilers (except for the 'external moisture' all other values are given as 'air-dry')

\begin{tabular}{|c|c|c|c|c|}
\hline Specification & Unit & Coal, PC & Coal, CFB & Biomass, CFB \\
\hline External moisture ${ }^{\text {as received }}$ & $\%$ & 14.01 & 15.1 & 39.5 \\
\hline Hygroscopic moisture & $\%$ & 4.78 & 5.02 & 6.21 \\
\hline Ash & $\%$ & 24.4 & 25.26 & 1.57 \\
\hline Volatile matter & $\%$ & 37.18 & 37.66 & 78.79 \\
\hline Fixed carbon & $\%$ & 33.64 & 32.06 & 13.43 \\
\hline HHV & $\mathrm{kJ} / \mathrm{kg}$ & 22700 & 23200 & 16100 \\
\hline Sulfur & $\%$ & 1.73 & 1.66 & 0.79 \\
\hline Carbon & $\%$ & 51.69 & 51.33 & 39.23 \\
\hline Hydrogen & $\%$ & 3.97 & 4.08 & 5.33 \\
\hline Nitrogen & $\%$ & 0.98 & 0.94 & 4.99 \\
\hline Mercury & $\mathrm{ng} / \mathrm{g}$ & 177 & 224 & 103 \\
\hline
\end{tabular}


cy modulation of light polarization and with no need to accumulate mercury on a gold sorbent. In order to record the instantaneous mercury concentration during the thermal treatment of solid samples the whole system was connected to a standard PC device.

The measurements of mercury concentration in the PC flue gas were carried out at three locations along the gas duct, i.e. before the ESP, after the ESP and after the wet flue gas desulfurization plant. In the case of CFB boiler, the mercury in the exhaust gases was carried out at two locations along the flue gas path i.e. before and after the electrostatic precipitator (ESP). Apart from determinations of the mercury concentration in the flue gases the samples of fuels, ashes, gypsum (wet FGD plant product) were also taken in order to determine their concentration of mercury.

The determination of mercury concentration in the flue gas was performed according to the socalled 'cold vapor' technique, while the $\mathrm{Hg}$ content in the solid samples was investigated with the use of the add-on RP-91C device. All proximate and ultimate analyses of the samples were carried out according to Polish/EU standards.

\section{RESULTS AND DISCUSSION}

The PC boiler war fired with hard coal. Composition of the coal is shown in Table 1. The CFB combustor was fired with a mixture of hard coal and biomass. Composition of both components is also shown in Table 1.

The comparison of the parameters of both coals indicates that the fuels are very similar. They contain roughly $25 \%$ of ash and slightly over $37 \%$ of volatile matter. The fixed carbon content varies from $32 \%$ to $33.6 \%$ for the samples taken from the CFB and PC system, respectively. The high heating value of the coals burned in the pulverized furnace boiler was determined as 22.7 $\mathrm{MJ} / \mathrm{kg}$, while the CFB combustor was fired with a fuel characterized by the HHV of $23.2 \mathrm{MJ} / \mathrm{kg}$.

Ultimate analysis results for both coals also indicate that they are very similar with respect to carbon, hydrogen, nitrogen, and sulfur content. However, the fuels are characterized by some differences in mercury content; the concentration of $\mathrm{Hg}$ in the coal combusted in the PC boiler was $177 \mathrm{ng} / \mathrm{g}$, while the corresponding value for the fuel burned in the CFB facility was roughly $20 \%$ higher i.e. $224 \mathrm{ng} / \mathrm{g}$.
Contrary to both coals, the analysis of the biomass parameters indicates that it contained much more moisture and volatiles (over $45 \%$ and $78 \%$, respectively) and much less ash and fixed carbon (roughly $1.5 \%$ and $13 \%$, respectively). Surprisingly, the biomass contained also quite high amount of sulfur (almost $0.8 \%$ ) and mercury (slightly over $100 \mathrm{ng} / \mathrm{g}$ ). Both elements are probably present in the local environment where the biomass was planted and from where it was harvested.

The results of mercury measurements are shown in Tables 2-5. As presented in Table 2, where the concentrations of mercury in solid samples taken from the pulverized coal fired boiler are shown, the highest concentrations of mercury were determined at gypsum and fly ash particles. Both values exceed the $\mathrm{Hg}$ concentra-

Table 2. Mercury concentration in solid samples taken from the PC boiler facility

\begin{tabular}{|c|c|}
\hline Sample & Mercury concentration [ng/g] \\
\hline Coal & 177 \\
\hline Sorbent & 7.2 \\
\hline Slag & 5.5 \\
\hline Fly ash & 246 \\
\hline Gypsum (wet FGD product) & 266 \\
\hline
\end{tabular}

Table 3. Mercury concentration in solid samples taken from the CFB boiler

\begin{tabular}{|c|c|}
\hline Sample & Mercury concentration [ng/g] \\
\hline Coal & 224 \\
\hline Biomass & 103 \\
\hline Sorbent & 4.7 \\
\hline Fly ash & 356 \\
\hline Bottom ash & $<1$ \\
\hline
\end{tabular}

Table 4. Mercury concentration at various locations in the flue gas duct from the PC boiler

\begin{tabular}{|c|c|}
\hline Sampling location & $\begin{array}{c}\text { Mercury concentration } \\
{\left[\mathrm{ng} / \mathrm{m}^{3}\right]}\end{array}$ \\
\hline Before ESP & 9.91 \\
\hline After ESP (before wet FGD) & 2.37 \\
\hline After wet FGD & 1.03 \\
\hline
\end{tabular}

Table 5. Mercury concentration in the flue gas from the CFB boiler

\begin{tabular}{|c|c|}
\hline Sampling location & $\begin{array}{c}\text { Mercury concentration } \\
{\left[\mathrm{ng} / \mathrm{m}^{3}\right]}\end{array}$ \\
\hline Before ESP & 3.82 \\
\hline After ESP & 0.96 \\
\hline
\end{tabular}


tion in coal, thus indicating that mercury is indeed evaporated in the boiler furnace and then accumulated onto fly ash and gypsum particles. The amount of mercury transported with the slag is much lower $(5.5 \mathrm{ng} / \mathrm{g})$.

As for the solid from the CFB combustor (cf. Table 3), the majority of mercury leaves the system bound on the fly ash samples. Bottom ash particles are almost mercury-free; probably due to their relatively long residence time in the furnace (long enough for the $\mathrm{Hg}$-compounds to evaporate) and intense attrition 'producing' numerous fine particles captured in the ESP.

The concentrations of $\mathrm{Hg}$ in the flue gases are shown in Tables 4 and 5 for PC and CFB boiler installations, respectively. The data obtained at the PC plant (cf. Table 4) indicate the decrease in the concentration of mercury in the flue gas along the flue gas path thus confirming positive effect of the particulate removal system and wet FGD facility to decrease the emission of $\mathrm{Hg}$ to the atmosphere from coal-burning installations. Similar results were obtained for the CFB combustor (cf. Table 5) - the outlet concentration of mercury does not exceed $1 \mathrm{ng} / \mathrm{Nm}^{3}$ and is of similar value to the concentration determined for the PC facility (cf. Table 4).

\section{CONCLUSIONS}

The results of the investigations briefly described in this paper and focused on the determination of mercury emission from selected solid fuel (coal and biomass) burning large-scale boilers indicate as follows:

1. The concentration of mercury in the fuel samples varied roughly between $100 \mathrm{ng} / \mathrm{g}$ for biomass and 180-225 ng/g for the coal samples.

2. The results carried out at both $\mathrm{PC}$ and $\mathrm{CFB}$ facilities confirmed the positive effect of the flue gas cleaning devices to decreasing and controlling the outlet concentration of mercury in the flue gas.
3. The highest concentration of $\mathrm{Hg}$ in solid samples was determined for fly ash and wet FGD products for the CFB and PC combustors, respectively.

\section{REFERENCES}

1. Sloss L., 2012. Legislation, standards and methods for mercury emission control, IEA Clean Coal Centre, CCC/195.

2. United Nation Environment Programme Chemicals, Global Mercury Assessment, UNEP Chemicals, Geneva, December 2002.

3. UNEP, 2013. Global Mercury Assessment 2013: Sources, Emissions, Releases and Environmental Transport. UNEP Chemicals Branch, Geneva, Switzerland.

4. Sloss L., 2008. Economics of mercury control, IEA Clean Coal Centre, CCC/134.

5. Hławiczka S., 2008. Rtęć w środowisku atmosferycznym, Instytut Podstaw Inżynierii Środowiska Polskiej Akademii Nauk, Zabrze.

6. Głodek A., Panasiuk D., Pacyna J.M., 2010. Mercury emission from anthropogenic sources In Poland and their scenarios to the year 2020, Water Air Soil Pollution 213, 227-236.

7. Grudziński Z., 2013. Fakty: Węgiel - Energetyka w Polsce, Instytut GSMiE PAN, WWW. min-pan.kraków.pl /zaklady/zrynek/cf_web.htm (20.09.2013).

8. Wojnar i Wisz 2006 - Wojnar K., Wisz J., 2006. Rtęć w polskiej energetyce, Energetyka 4(59).

9. Głodek, A., Pacyna, J.M., 2009, Mercury emission from coal-fired power plants in Poland, Atmospheric Environment, 43, 5668-5673.

10. Wichliński M. Kobyłecki R., Bis Z., 2013. The investigation of mercury contents in polish coal samples, Archives of Environmental Protection, 39(2), 141-150.

11. Zyśk J., Wyrwa A., Pluta M., 2011. Emissions of mercury from the power sector in Poland. Atmospheric Enviroment 45, 605-610.

12. Hławiczka S., Fudała J., 2008. Assessment of Atmospheric Mercury Emission Reduction Measures Relevant for Application in Poland, Environmental Engineering Science, 25(2). 